\title{
WHY LYCOSPORA DOMINATED MANY PENNSYLVANIAN SPORE ASSEMBLAGES
}

\author{
BARRY A. THOMAS \\ Institute of Biological, Environmental and Rural Sciences, Aberystwyth University, Penglais, Aberystwyth, Ceredigion SY23 1NL, United \\ Kingdom; e-mail: bat@aber.ac.uk.
}

Thomas, B. A. (2021): Why Lycospora dominated many Pennsylvanian spore assemblages. - Fossil Imprint, 77(1): 11-16, Praha. ISSN 2533-4050 (print), ISSN 2533-4069 (on-line).

\begin{abstract}
The microspore genus Lycospora in its wider sense is produced by both heterosporous cones, Flemingites, and homosporous cones Lepidostrobus. Calculations are made of the number of microspores that are produced by cones and then by individual Pennsylvannian arborescent lycophytes. The distribution of the rooting rhizohores, Stigmaria can be extrapolated to a square kilometre of forest. A calculation of the number of spores produced in such a forest is enormous which explains why some dispersed spore floras are dominated by these spores. There are dispersed spore assemblages prepared from coal with high percentages of Lycospora. However, the methods of preparation and counting of the spores do not give enough information to make a meaningful calculation of their total numbers in the samples.
\end{abstract}

Key words: Lycospora, arborescent lycophytes, Flemingites, Lepidostrobus, coal seams, Pennsylvannian

Received: July 18, 2020 | Accepted: October 25, 2020 | Issued: December 9, 2021

\section{Introduction}

The arborescent lycophytes Lepidodendron STERNB. and Lepidophloios STERnB. grew in the extensive Pennsylvannian swamps where they often dominated the vegetation. The discovery of clusters of their rooting organs, called Stigmaria BRONGN., suggests that the arborescent lycophytes grew at the same time to form closed forests (McGregor and Walton 1972, Thomas and Seyfullah 2015). The fossilized remains of these lycophytes reveal a diversity of form, with some of them growing up to ca. $45 \mathrm{~m}$ in height, with the basal parts of their trunks up to $2 \mathrm{~m}$ in diameter (Thomas and Watson 1976, Thomas and Seyfullah 2015). The plants had determinate growth patterns and started life as an unbranched leafy stem that grew vertically and expanded in diameter until it finally branched in a variety of ways to produce either a crown of dichotomizing branches or a series of lateral dichotomizing branches (Thomas 1978, Bateman et al. 1992, DiMichele et al. 2013).

It is of course impossible to know the precise length of time it took arborescent lycophytes to grow and reach fertile maturity. Indeed, it is highly probable that some types of plants became fertile long before others. The autecology of the arborescent lycophytes does however suggest that they were very fast growing trees. This is supported by the economic construction of the stems that had little secondary xylem, the large number of stomata that they possessed, the persistence of the laminae, and the relatively well-illuminated conditions in which the young plants grew (Thomas and
Cleal 2018). Maturity would have been reached in much less time than its takes conifer and angiosperm trees to do so. The large "ulodendroid" scars that are borne by some stems such as Lepidodendron veltheimii STERnB. (e.g., Hirmer 1927), Lepidodendron nathorstii KIDST. (e.g., Crookall 1966: pl. 67, fig. 1), Bothrodendon minutifolium Boulay (Lindsey 1915) and Ulodendron majus LindL. et HutTon (Lindley and Hutton 1831) most probably show the positions of abscised branches that may have borne cones. Such a growth pattern would have produced cones while the plant was still growing. Others with a crown of dichotomizing branches would have almost certainly reached full size before becoming fertile with cones on their terminal branches. Ultimately, after the plants reached full size and ceased to produce cones they presumably died and started to decay, otherwise the next generation of plants would have been suppressed through over-crowding and shading.

Descriptions of in situ spores recovered from the fructifications of arborescent lycophytes have been published many times (e.g., Thomas 1970, Thomas and Dytko 1980, Thomas et al. 2009, Drábková et al. 2004, Bek and Opluštil 2006, Bek et al. 2008, 2009a, b, Opluštil and Bek 2009, Bek 2012, 2013, 2017, Thomas and Bek 2014). Some arborescent lycophytes, such as Lepidodendron STERNB. produced bisporangiate cones, called Flemingites CArruth. (emended by Brack-Hanes and Thomas 1983), that contained Microspinosporites BEK microspores and Lagenicula (BenNie et Kidst.) R.Potonié et Kremp / Lagenoisporites R.PotoniÉ et KREMP megaspores. Others, 

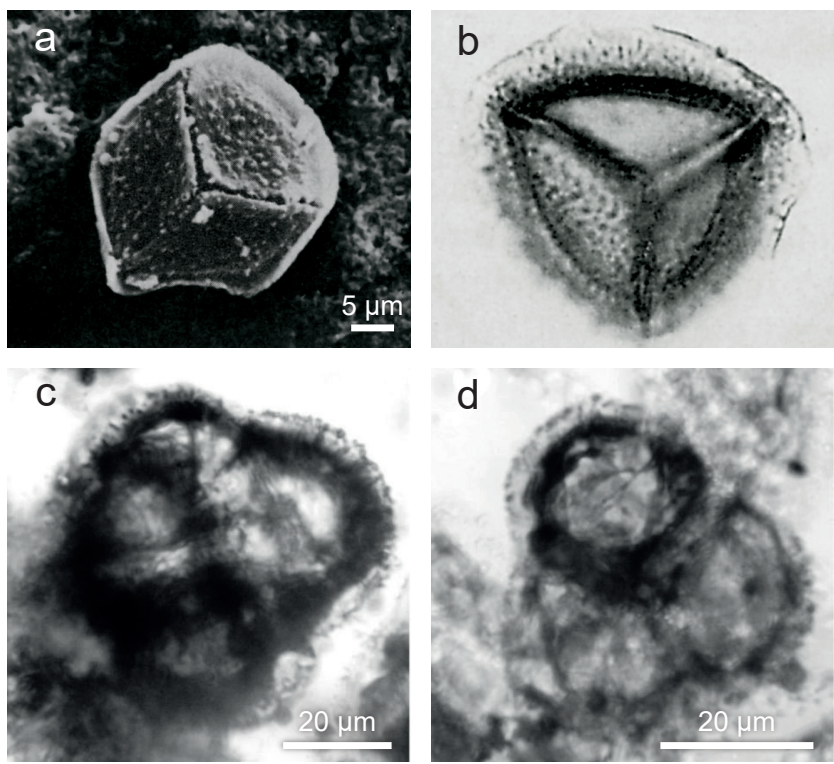

Text-fig. 1. Lycospora. a: Microspore from the bisporangiate cone Flemingites gracilis CARRUTH. (from Brack-Hanes and Thomas 1983). This type of microspore should be referred to Microspinosporites BEK. b: Flanged microspore from the microsporangiate cone Lepidostrobus binneyanus A.ARBER (from Thomas 1970), same magnification as in (a). c, d: Microscpores from the microsporangiate cone Lepidostrobus brownii (UNGER) ScHIMP. (from Thomas and Bek 2014).

such as Lepidophloios STERNB. produced monosporangiate cones with Cappasporites L.L.URB. microspores and Cystosporites diabolicus (H.V.ScotT) A.R.HemsL. seedlike megaspores in Achlamydocarpon Schum.-Lambry. The third type produced monosporangiate cones called Lepidostrobus BRONGN. (emended by Brack-Hanes and Thomas 1983) that contained Lycospora J.M.SCHOPF, L.R.Wilson et Bentall (emended by Potonié and Kremp 1954) microspores (Text-fig. 1) and Cystosporites giganteus (ZERNDT) J.M.Schopf (sensu Dijkstra 1946) seed-like megaspores in Lepidocarpon D.H.Sсотт. The sigillarian lycophytes cones called Sigillariostrobus (Schimp.) Feistm. were monosporangiate with either had Crassispora D.C.BHARDWAJ microspores or Laevigatisporites R.POTONIÉ et GelLETICH / Tuberculatisporites A.C.IBRAHIM megaspores. The bisporangiate cone Thomasostrobus OpLUŠTIL, BEK et DrábKové contained Cadiospora KosAnKe microspores and Sublagenicula PIÉRART megaspores. The major problem is that there has been no distinction between Lycospora and Microspinosporites in the literature so for the purposes of this paper all comments and calculation refer to Lycospora.

Schopf et al. (1944), Potonié and Kremp (1954) and Somers et al. (1972) mentioned a great number of Lycospora species including holotypes. Microspores, known to have come from arborescent lycophytes, can be prepared both from coal seams, where they can be related to the coal petrology (Smith 1962, 1964, 1968, Kosanke 1988), and from sediments associated with the coals (e.g., Alpern 1963, Peppers 1964, 1997, Dimitrova et al. 2005, 2010).

The knowledge of the affinities of these fructifications makes it possible to suggest palaeoecological interpretations from the microspore assemblages (Thomas and Dimitrova 2017).

\section{Calculations of in situ Lycospora produced by forests of arborescent lycophytes}

Even though there are many accounts of arborescent cones and their spores, as yet there has been no attempt to estimate the number of spores that were released from these plants. In studying museum collection specimens and published figures of branching, the dichotomies on average appear to reduce the diameters of the stems to approximately $55 \%$ of the original size. Accepting that the vertical stem tapered upwards, the diameter of the terminal part of the main trunk would have been approximately one meter in diameter. It would take 10 dichotomies to reduce the diameter to about $2.5 \mathrm{~mm}$, which is the approximate size of the terminal shoots (Text-fig. 2). This calculation involving reductions in diameter would result in approximately 1,000 terminal branches on a mature tree. Studies of the plant assemblages at Brymbo, North Wales (Thomas et al. 2020) revealed that the number of small leafy shoots bearing terminal cones (Text-fig. 3) is less than the number of similar sized shoots not bearing terminal cones. This suggests that either cones had been dehisced from the terminal shoots or not all the shoots produced cones. If it is the latter, it is possible that only the outermost shoots produced cones. So, assuming a low number of shoots with terminal cones to be approximately $45 \%$ of the total, it would mean that a plant produced approximately 450 cones.

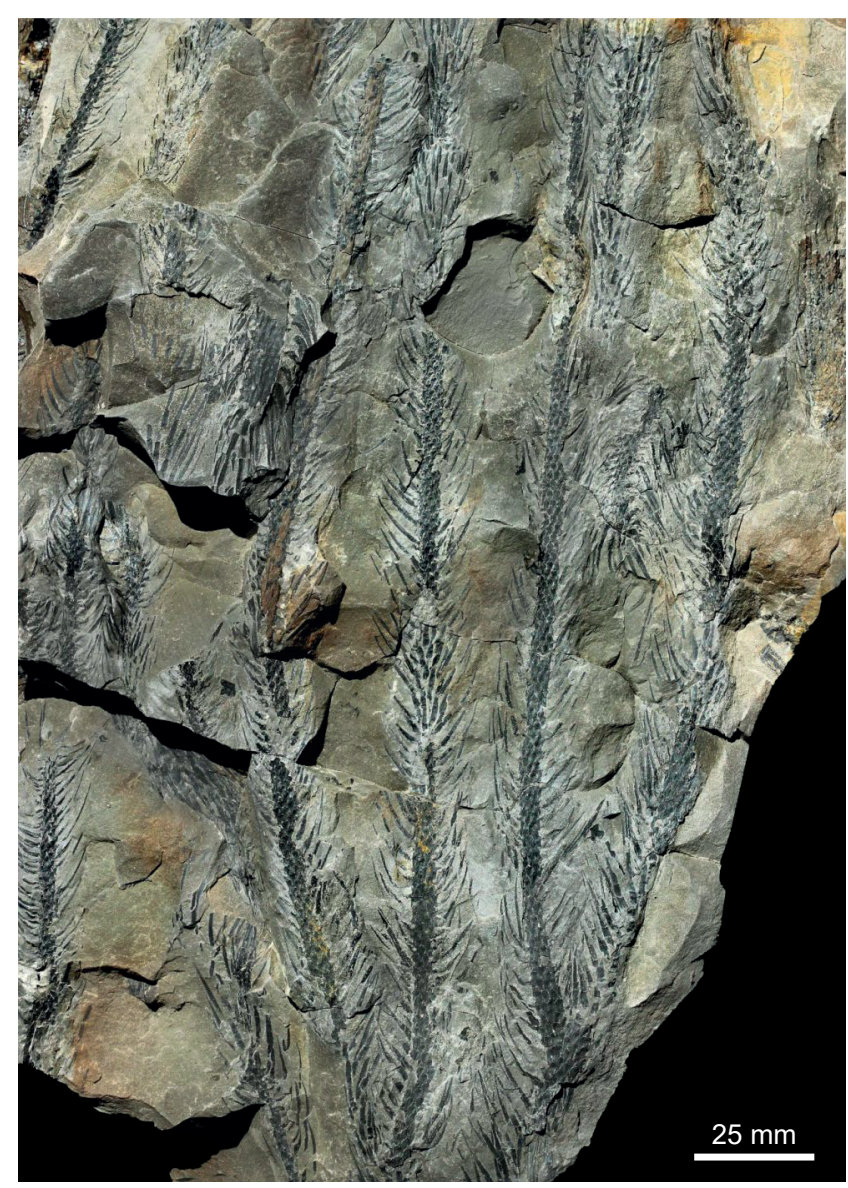

Text-fig. 2. Dichotomising terminal shoots of Lepidodendron ophiurus Brongn. from Brymbo (bed C4). No 2013.43G.147 (National Museum of Wales) (from Thomas et al. 2019). 


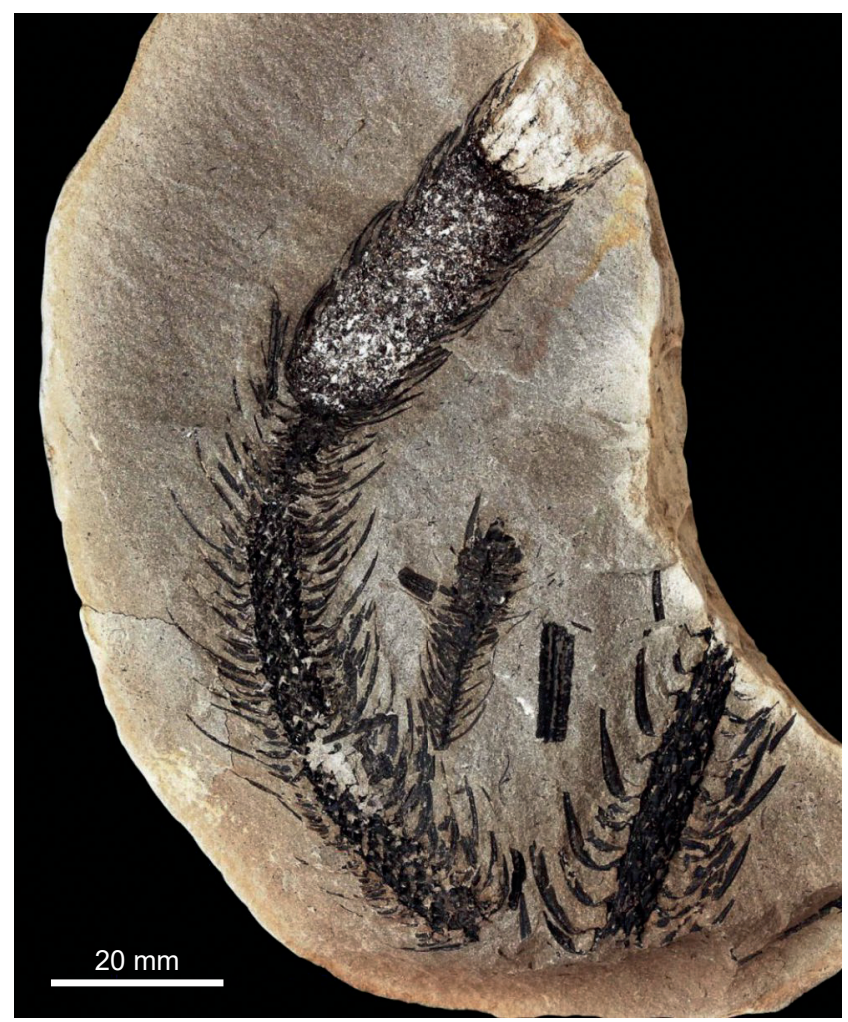

Text-fig. 3. Terminal cone attached to Lepidodendron ophiurus Brongn., leafy shoot. No. 2013.43G.120 (National Museum of Wales).

Cones vary considerably in size, but an average length of a bisporangiate cone, referable to Flemingites CARruth., is about $130 \mathrm{~mm}$ long in which the lower $1 / 3$ is megasporangiate and the upper $2 / 3$ microsporangiate. With 13 fertile sporophylls per whorl (see Thomas and Bek 2014) this would suggests approximately 150 microsporangia in an average sized cone. In microsporagiate cones, referable to Lepidostrobus BRONGN., the number would be higher and of the order of 190 .

Calculating the number of microspores in a microsporangium is difficult. Microspores develop in tetrads through meiosis and they are often seen in tetrads in cones preserved as petrifactions. Lepidostrobus brownii SCHIMP. is such a cone and measuring the diameter of tetrads in sections as ca. $50 \mu \mathrm{m}$, gives means of determining the number of spores in a single sporangium (fig. 4 from Thomas and Bek 2014). The sporangia are $13 \mathrm{~mm}$ long, $7 \mathrm{~mm}$ tall and $3 \mathrm{~mm}$ wide in the central part but they become smaller distally. Estimating the average internal width and height to be $2 / 3$ of the maximum size gives a volume of $12 \times 4.7 \times 2=$ $122 \mathrm{~mm}^{3}$. Taking the volume of tetrads to be ca. $50 \mu \mathrm{m}^{3}$ and accepting there will be some space between them the estimate of the number of tetrads is 650 , which would result in there being 2,600 microspores per sporangium. Taking these numbers it would result in a bisporangiate cone with 150 microsporangia producing about 390,000 microspores, whereas a microsporangiate cone with 190 sporangia would produce about 494,000 microspores. Taking the calculated figure of 450 cones per mature plant, the number of microspores produced by single mature plants would be of the order of 175 million and 222 million respectively.
Some cones of the Lepidostrobus crassus/sternbergii type are known to be almost one meter long so the number of Lycospora in such a long cone would have been enormous compared to the average size of $10-15 \mathrm{~cm}$ and probably being of the order of 5 million. Following the assumptions above, a mature plant with such cones would produce 2,220 million spores.

Stands of Stigmaria permit an estimation to be made of the abundance of arborescent lycophytes. For example, an extrapolation from the 11 Stigmaria in the Glasgow Fossil Grove (see Thomas and Seyfullah 2015) gives an estimate of about 4,500 trees per square kilometre (Gastaldo 1986), thus suggesting a very dense coverage of arborescent lycophytes. Dominance of Lepidodendron cannot be assumed over the toral area so supposing it to be over two-thirds of the area, the number of microspores from such extensive forests would, therefore, be somewhere in the region of 500,000 million per $\mathrm{km}^{2}$ (or 5,000,000 million if using the meter-long cones).

\section{Discussion}

Given such huge numbers of microspores being produced by the lycophyte forests it is not surprising that some spore assemblages, from coals of Pennsylvannian (especially Westphalian) age, described in the literature are dominated by Lycospora. Kremp (1952) suggested an alternation of forest and open moor associations and showed changes in spore content corresponding to changes in coal lithology. He also demonstrated the microscopical evidence of wood in his "forest produced coal" agreeing with the work of Hickling and Marshall (1933), who had described arborescent lycopod bark as only occurring in Carboniferous coals of a similar petrographical kind. Teichmüller (1952) and Teichmüller and Teichmüller (1968) also proposed a relationship between coal lithology and plant assemblages. Smith $(1957,1962,1964,1968)$ refined this spore work to suggest that there were four basic plant communities, which were likely to have been controlled by an interplay of water table and climatic conditions of humidity, rainfall and temperature. His work, supported by that of Habib and Groth (1967), showed that the lycophyte forests, characterised by abundant Lycospora, were the first to actively produce peat. This is, of course, consistent with the occurrence of Stigmaria in the seat earths below the coal seams. Such forests, which were probably formed in standing water, usually gave way to the more open communities that were richer in species and had many calamites and ferns. It either reverted to lycophyte forest, or less frequently to an open moor type of vegetation dominated by smaller, subarborescent lycophytes. This gradual change to the open moor is thought to have been produced by a combination of climatic change and a drying of the peat surface, either by growth above the water table or by a withdrawal of surface water. Any subsequent flooding of the peat surface would have produced a reversion to the lycophyte forest. Smith's interpretation of plant communities can perhaps be taken a little further. Smith's transition zone suggests a mixed assemblage, reflecting an open community growing in wet peat rather than open water. Fern spores and Crassispora (the microspore of Sigillaria BRONGN.) were present, but 
there was also Lycospora (Microspiosporites) granulate KosAnke showing that bisporangiate lepidodendroids (i.e., Lepidodendron producing Flemingites) were present. Butterworth (1964) illustrated lateral differences in spore floras showing that the lycopod forests were more common and lasted longer in the central areas of the coal measure basins, while the more open moor communities occurred mostly towards the edges of the basins.

There have been a number of published accounts showing that Lycospora numbers were very high in many samples. For example, Thomas and Dimitrova (2015) recorded Lycospora as $58 \%$ of the total spores and $96.5 \%$ of the lycophyte spores in the roofing shales above the Asturian No. 2 Llantwit Seam in the South Wales Coalfield and $45 \%$ of the total spores and $85 \%$ of the lycophyte spores in the Asturian Brazilly Seam in the Forest of Dean Coalfield. A preliminary study of the North American Coalfields also shows similar occasions when spore assemblages were dominated by Lycospora. For example, in the Gilbert Coal (Lower and Upper Benches) of the West Virginia coalfield described by Kosanke (1988) Lycospora was $77 \%$ and $85 \%$ of the total spore contents of the Benches. However, Peppers (1964), who used the Kosanke (1950) technique of preparing microspores, explained that only a small portion of the filtered spore residue from each sample was taken for examination. So when Kosanke (1988) counted 200 spores from his $50 \mathrm{~g}$ sample of coal it was only a very small percentage of the spores prepared from the samples. If the whole microspore residue had been examined and all the spores counted the number would have been very much larger. It would also have provided a means of comparing the numbers of Lycospora produced from the plants to that in the coal.
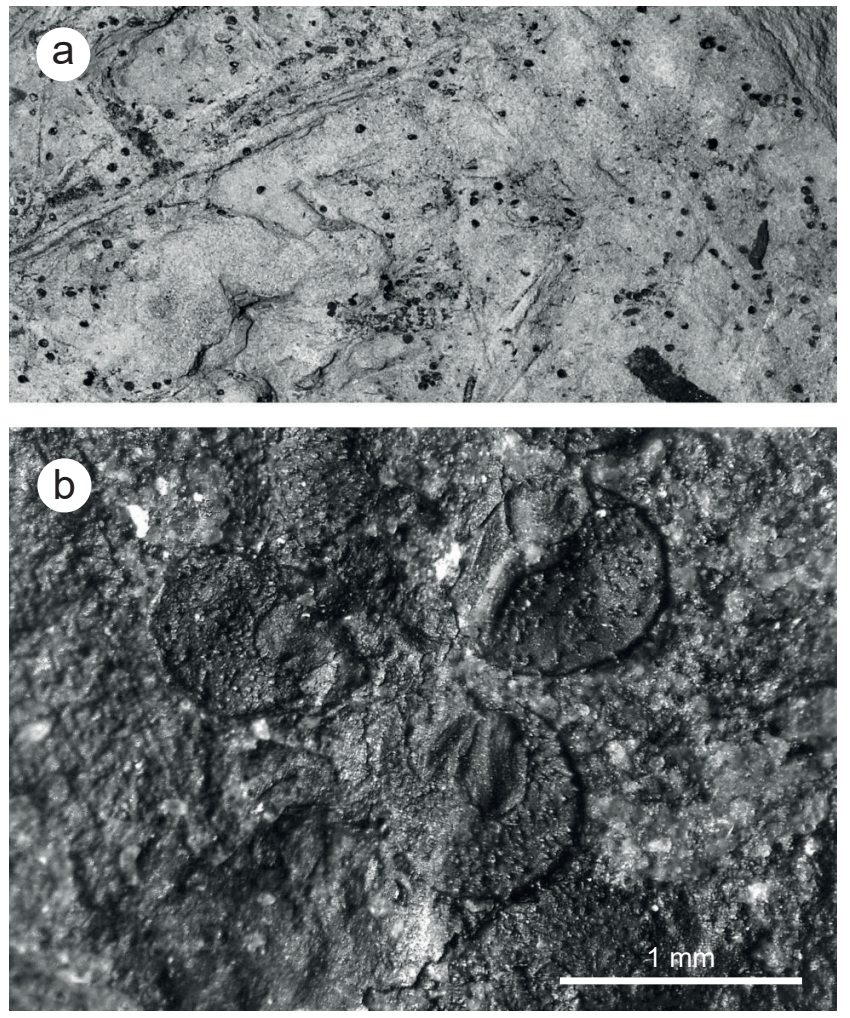

Text-fig. 4. Dispersed megaspores on the surface of $1,000 \mathrm{~mm}^{2}$ of shale at Brymbo (a) with an enlargement showing Lagenicula horrida ZERNDT (b).

\section{Conclusion}

It is generally accepted that arborescent lepidodendroids dominated much of the Euramerican coal swamps in the early Pennsylvanian and that the number of plants in these forests was huge. From the calculations of the number of cones on mature arborescent lepidodendroids and the number of spores that these cones produced the swamp surface must have been densely covered by Lycospora. Under such circumstances it is not surprising that Lycospora dominates the spore counts in so many coals. It is however impossible to calculate the total number of Lycospora in the coal because of the very limited sizes of the counts. It is also certain that the plants must have produced very large numbers of megaspores and occasionally they are visible on the surface of sediments (Text-fig. 4). Unfortunately, yet there have been no attempts to quantify the numbers of the different genera and species in either coals or sediments.

\section{References}

Alpern, B. (1963): Coupe palynologique du Westphalien du bassin houiller de Lorraine. - Comptes rendus hebdomadaires des séances de l'Académie des sciences, Paris, 256: 5170-5172.

Bateman, R. M., DiMichele, W. A., Willard, D. A. (1992): Experimental cladistic analysis of anatomically preserved arborescent lycopsids from the Carboniferous of Euramerica: an essay on paleobotanical phylogenetics. Annals of the Missouri Botanical Garden, 79: 500-559. https://doi.org/10.2307/2399752

Bek, J. (2012): A review of the genus Lycospora. - Review of Palaeobotany and Palynology, 174: 122-135. https://doi.org/10.1016/j.revpalbo.2011.12.008

Bek, J. (2013): Microspinosporites, a new genus of Palaeozoic pseudosaccate microspores of flemingitalean affinity. - Bulletin of Geosciences, 88: 573-581. https://doi.org/10.3140/bull.geosci.1365

Bek, J. (2017): Palaeozoic in situ spores and pollen. Lycopsida. - Palaeontographica, B, 296: 1-111. https://doi.org/10.1127/palb/296/2017/1

Bek, J., Drábková, J., Dašková, J., Libertín, M. (2008): The sub-arborescent lycopsid genus Polysporia Newberry and its spores from the Pennsylvanian (Bolsovian-Stephanian B) continental basins of the Czech Republic. - Review of Palaeobotany and Palynology, 152: 176-199. https://doi.org/10.1016/j.revpalbo.2008.05.002

Bek, J., Libertín, M., Drábková, J. (2009a): Selaginella labutae sp. nov., a new compression herbaceous lycopsid and its spores from the Kladno-Rakovník Basin, Bolsovian of the Czech Republic. - Review of Palaeobotany and Palynology, 155: 101-115.

https://doi.org/10.1016/j.revpalbo.2007.12.010

Bek, J., Libertín, M., Drábková, J. (2009b): Spencerites leismanii sp. nov., a new sub-arborescent compression lycopsid and its spores from the Pennsylvanian of the Czech Republic. - Review of Palaeobotany and Palynology, 155: 116-132.

https://doi.org/10.1016/j.revpalbo.2007.12.007 
Bek, J., Opluštil, S. (2006): Six rare Lepidostrobus species from the Pennsylvanian of the Czech Republic and their bearing on the classification of lycospores. - Review of Palaeobotany and Palynology, 139: 211-226. https://doi.org/10.1016/j.revpalbo.2006.01.003

Brack-Hanes, S. D., Thomas, B. A. (1983): A re-examination of Lepidostrobus Brongniart. - Botanical Journal of the Linnean Society, 86: 125-133. https://doi.org/10.1111/j.1095-8339.1983.tb00720.x

Butterworth, M. A. (1964): Die Verteilung der Densosporites sphaerotriangularis im Westfal Steinkohlenfelder Englands. - Fortschritte in der Geologie von Rheinland und Westfalen, 12: 317-330.

Crookall, R. (1966): Fossil Plants of the Carboniferous rocks of Great Britain [Second section]. - Memoir of the Geological Survey of Great Britain, Palaeontology, 4(3): ix-xii, 217-354.

DiMichele, W. A., Elrick, S. D., Bateman, R. M. (2013): Growth habit of the late Paleozoic rhizomorphic treelycopsid family Diaphorodendraceae: phylogenetic, evolutionary, and paleoecological significance. - American Journal of Botany, 100: 1604-1625. https://doi.org/10.3732/ajb.1200623

Dimitrova, T. K., Cleal, C. J., Thomas, B. A. (2005): Palynology of late Westphalian-early Stephanian coal-bearing deposits in the eastern South Wales Coalfield. Geological Magazine, 142: 809-821. https://doi.org/10.1017/S001675680500107X

Dimitrova, T. K., Zodrow, E. L., Cleal, C. J., Thomas, B. A. (2010): Palynological evidence for Pennsylvanian (Late Carboniferous) vegetation change in the Sydney Coalfield, eastern Canada. - Geological Journal, 45: 388-396. https://doi.org/10.1002/gj.1179

Drábková, J., Bek, J., Opluštil, S. (2004): The first compression fossils of Spencerites (Scott) emend., and its isospores, from the Bolsovian (Pennsylvanian) of the Kladno-Rakovník and Radnice basins, Czech Republic. - Review of Palaeobotany and Palynology, 130(1-4): 59-88. https://doi.org/10.1016/j.revpalbo.2004.01.004

Gastaldo, R. A. (1986): An explanation for lycopod configuration. 'Fossil Grove' Victoria Park, Glasgow. - Scottish Journal of Geology, 22: 77-83. https://doi.org/10.1144/sjg22010077

Habib, D., Groth, P. K. H. (1967): Paleoecology of migrating Carboniferous Peat environments. - Palaeogeography, Palaeoclimatology, Palaeoecology, 3: 185-195. https://doi.org/10.1016/0031-0182(67)90013-2

Hickling, H. G. A., Marshall, C. E. (1933): The microstructure of the coal of certain fossil tree barks. - Transactions of the Institute of Mining Engineers, 86: 65-75.

Hirmer, M. (1927): Handbuch der Paläobotanik. - R. Oldenbourg, München, Berlin, 708 pp.

Kosanke, R. M. (1950): Pennsylvanian spores of Illinois and their use in correlation. - Bulletin, Illinois State Geological Survey, 74: 1-129. https://doi.org/10.5962/bhl.title.61458

Kosanke, R. M. (1988): Palynological studies of Lower Pennsylvanian Coal Beds and adjacent Strata of the proposed Pennsylvanian system Stratotype in Virginia and
West Virginia. - U.S. Geological Survey Professional Paper, 1479: 1-17.

https://doi.org/10.3133/pp1479

Kremp, G. (1952): Sporen-Vergesellschaftungen und Mikrofaunen-Horizonte im Ruhrkarbon. - In: Comte rendu publié sous la rédaction du Geologisch bureau Heerlen, Troisème Congrès pour l'avancement des études de stratigraphie et de géologie du Carbifère, Tome I. Ernest van Aelst, Maestricht, pp. 347-357.

Lindsey, M. (1915): The branching and branch shedding of Bothrodendron. - Annals of Botany, 29: 223-230. https://doi.org/10.1093/oxfordjournals.aob.a089542

Lindley, J., Hutton, W. (1831): The fossil flora of Great Britain. Vol. 1, Pt. 1. - W. J. Ridgeway and Sons, London, 30 pp. +10 pls.

McGregor, M., Walton, J. (1972): The Story of the Fossil Grove at Glasgow Public Parks and Botanical Gardens, revised edition. - Glasgow DC Parks Department, Glasgow, $32 \mathrm{pp}$.

Opluštil, S., Bek, J. (2009): Some Pennsylvanian arborescent lycopsid cones and their microspores from the British coalfields. - Bulletin of Geosciences, 84: 203-225. https://doi.org/10.3140/bull.geosci.1081

Peppers, R. A. (1964): Spores in strata of Late Pennsylvanian cyclothems in the Illinois Basin. - Illinois State Geological Survey Bulletin, 90: 1-89. https://doi.org/10.5962/bhl.title.61522

Peppers, R. A. (1966): Palynological Correlation of Major Pennsylvanian (Middle and Upper Carboniferous) Chronostratigraphic Boundaries in the Illinois and Other Coal Basins. - Memoir, Geological Society of America, 188: 1-111.

Peppers, R. A. (1997): Palynology of the lost branch formation of Kansas - new insights on the major floral transition at the middle-upper Pennsylvanian boundary. Review of Palaeobotany and Palynology, 98: 223-246. https://doi.org/10.1016/S0034-6667(97)00013-4

Potonié, R., Kremp, G. (1954): Die Gattungen der Paläozoischen sporae dispersae und ihre Stratigraphie. - Geologische Jahrbuch, 69: 111-193.

Potonié, R., Kremp, G. (1955): Die sporae dispersae des Ruhrkarbons, ihre Morphographie und Stratigraphie mit Ausblicken auf Arten anderer Gebiete und Zeitabschnitte [Teil I]. - Palaeontographica, B, 98(1-3): 1-136.

Schopf, J. M., Wilson, L. R., Bentall, R. (1944): An anotated synopsis of Paleozoic fossil spores and the definition of generic groups. - Illinois Geological Survey Report of Investigations, 91: 1-73. https://doi.org/10.5962/bhl.title.61674

Smith, A. H. V. (1957): The sequence of microspore assemblages associated with the occurrence of crassidurite in coal seams of Yorkshire. - Geological Magazine, 94: 345-363. https://doi.org/10.1017/S0016756800069399

Smith, A. H. V. (1962): The Palaeoecology of Carboniferous Peats based on the Microspores and Petrography of Bituminous Coals. - Proceedings of the Yorkshire Geological Society, 33: 423-474. https://doi.org/10.1144/pygs.33.4.423

Smith, A. H. V. (1964): Palaeoecology of Carboniferous peats. - In: Narin, A. E. M. (ed.), Problems in Palaeo- 
climatology, Proceedings of the NATO Palaeoclimates Conference held at the University of Newcastle upon Tyne January 7-12, 1963. Interscience Publishers, London, New York, pp. 57-75.

Smith, A. H. V. (1968): Seam Profiles and seam characters. In: Murchison, D. G., Westoll, T. S. (eds), Coal and Coalbearing Strata. Oliver and Boyd, Edinburgh, pp. 31-40.

Smith, A. H. V., Butterworth, M. A. (1967): Microspores in the coal seams of the Carboniferous of Great Britain. Special Papers in Palaeontology, 1: 1-324.

Somers, Y., Alpern, B., Doubinger, J., Grebe, H. (1972): Revision du genre Lycospora Schopf, Wilson \& Bentall. - In: Alpern, B., Streel, M. (eds), Les Spores 5. Microfossiles organiques du Paléozoïque. Centre national de la Recherche scientifique (CNRS), Paris, pp. 9-110.

Teichmüller, M. (1952): Vergleichende mikroskopische Untersuchungen versteinerter Torfe des Ruhrkarbons und der daraus entstandenen Steinkohlen. - In: Comte rendu publié sous la rédaction du Geologisch bureau Heerlen, Troisème Congrès pour l'avancement des études de stratigraphie et de géologie du Carbifère, Tome II. Ernest van Aelst, Maestricht, pp. 607-613.

Teichmüller, M., Teichmüller, R. (1968): Cainzoic and Mesozoic Coal Deposits of Germany. - In: Murchison, D. G., Westoll, T. S. (eds), Coal and Coal Bearing Strata. Oliver and Boyd, Edinburgh, pp. 347-379.

Thomas, B. A. (1970): A new specimen of Lepidostrobus binneyanus from the Westphalian B of Yorkshire. - Pollen et Spores, 12: 217-234.

Thomas, B. A. (1978): Carboniferous Lepidodendraceae and Lepidocarpaceae. - The Botanical Review, 44: 321-364. https://doi.org/10.1007/BF02957853

Thomas, B. A., Appleton, P., Cleal, C. J., Seyfullah, L. J. (2020): The distribution of plant fossils and their palaeoecology in Duckmantian (Bashkirian, Lower Pennsylvanian) strata at Brymbo, North Wales, UK. - Geological
Journal, 55(4): 3179-3207 [published on-line 18 July 2019].

https://doi.org/10.1002/gj.3529

Thomas, B. A., Bek, J. (2014): A reassessment of the Pennsylvanian lycophyte cone Triplosporite Brown. - Acta Geologica Polonica, 64: 139-145. https://doi.org/10.2478/agp-2014-0008

Thomas, B. A., Bek, J., Opluštil, S. (2009): A new species of Lepidostrobus from the early Westphalian of South Joggins, Nova Scotia, Canada. - Bulletin of Geosciences, 84(4): 661-666. https://doi.org/10.3140/bull.geosci.1133

Thomas, B. A., Cleal, C. J. (2018): Arborescent lycophyte growth in the late Carboniferous coal swamps. - New Phytologist, 218: 885-890. https://doi.org/10.1111/nph.14903

Thomas, B. A., Dytko, A. (1980): Lepidostrobus haslingdenensis: A new species from the Lancashire Millstone Grit. - Geological Journal, 15: 137-142. https://doi.org/10.1002/gj.3350150207

Thomas, B. A., Dimitrova, T. K. (2017): Ecological changes in Pennsylvanian (Asturian and early Cantabrian) coal floras inferred from lycophyte microspore abundances. Earth Science Reviews, 171: 642-662. https://doi.org/10.1016/j.earscirev.2017.05.008

Thomas, B. A., Seyfullah, L. J. (2015): Stigmaria Brongniart: a new specimen from Duckmantian (Lower Pennsylvanian) Brymbo (Wrexham, North Wales) together with a review of known casts and how they were preserved. - Geological Magazine,152(5): 858-870. https://doi.org/10.1017/S0016756815000035

Thomas, B. A., Watson, J. (1976): A rediscovered 114-foot Lepidodendron from Bolton, Lancashire. - Geological Journal, 11: 15-20. https://doi.org/10.1002/gj.3350110102 